\author{
Zh.T. Yeveskina ${ }^{1, *}$, A.M. Nurgaliyeva ${ }^{2}$, L.A. Chaykovskaya ${ }^{3}$ \\ ${ }^{1,2}$ Narxoz University, Republic of Kazakhstan \\ ${ }^{3}$ Plekhanov Russian University of Economics, Russian Federation \\ IShanart72@mail.ru, 2aliya.nurgalieva@narxoz.kz,.'chaykovskaya.l.a@mail.ru \\ ${ }^{1}$ https://orcid.org/0000-0003-4791-7003, ${ }^{2}$ http:// orcid.org/0000-0001-6044-6926, \\ ${ }^{3}$ https://orcid.org/0000-0002-1292-402X \\ ${ }^{2}$ Scopus Author ID: 559334946000, ${ }^{3}$ Scopus Author ID: 57192888110 \\ Researcher ID: ${ }^{2} Y-2788-2018,{ }^{3} G-7275-2017$
}

\title{
The profitability of second-tier banks: essence and main influencing factors
}

\begin{abstract}
Object. In this article, based on the aggregate indicators of second-tier banks of the Republic of Kazakhstan, what factors and how they affect the net income of the bank is determined.

Methods. During the analysis, a correlation-regression analysis of banking data was carried out using the Stata statistical package, and conclusions were drawn.

Findings. To identify the factors that affect the profitability of banks, the interdependencies between the selected indicators were identified. The correlation analysis revealed the relationship between the selected factors and the bank's net income. The density of bonds was determined by testing hypotheses calculated based on pair correlation coefficients.

Conclusions. The factor analysis carried out made it possible to identify the main factors affecting the bank's activities and assess the degree of their impact. As a result of the analysis of factors affecting the bank's income in the aggregate indicator of second-tier banks of the Republic of Kazakhstan, the compliance of the results obtained with the expected results was determined.
\end{abstract}

Keywords: bank efficiency, bank income, bank expenses, net profit, operational efficiency, correlation analysis, regression analysis.

\section{Introduction}

Banks are among the fastest and most effective emerging market structures in the economy. Of course, the condition for the bank's profitability is the preservation of liquidity and profit management. The amount of profit or loss received by the bank reflects the results of all its active and passive operations.

The main and most important indicator of the bank's performance is the bank's net profit, which is the final financial result for a certain reporting period. The amount of profit received affects the increase in the bank's fixed assets, the growth of equity, ensuring the stability of its financial condition and liquidity of the balance sheet, the level of dividends paid, and improving the development and quality of banking services provided.

In accordance with accounting requirements, the profit of commercial banks is determined by reducing the total amount of income by the number of expenses received as a result of the Bank's financial and economic activities (Novoselskaya et al., 2012).

When assessing the effectiveness of banks, a special role is given to the system of indicators that disclose the final financial results. Their analysis allows us to assess the effectiveness and financial condition of commercial banks. Successful financial stability management requires an effective choice of management methods and an assessment of financial performance (Zhakupova et al.,2020).

In the process of assessing the bank's profitability, it is necessary to conduct a factor analysis of the bank's profitability to identify the main sources of profit growth and sources of its decline. As a result, the composition of the yield is calculated in detail and the impact of changes in each of them on the change in the total yield is determined (Voloshina, 2014).

Therefore, the study of profit, its components, and factors affecting its dynamics is one of the most urgent problems in the financial analysis of the commercial bank's activities. The analysis of the main indicators of the bank's activity can be carried out using various methods, including economic and mathematical.

\footnotetext{
${ }^{*}$ Corresponding author.

E-mail address: Shanart72@mail.ru
} 
The relevance of using mathematical methods in banking activities makes it possible to find the best options for solving problems of commercial activity and is a promising direction of banking planning.

Without a deep and comprehensive study of factors, it is impossible to draw reasonable conclusions about the results of activities, justify plans and management decisions. Therefore, in our work, we conducted a study of the bank's profit using correlation-regression analysis using the Stata application package.

\section{Literary Review}

Each resulting performance indicator (profit) depends on many and different factors. The more detailed the influence factors on the value of the effective index, the more accurate and objective analysis and assessment of the quality of banking activities. Therefore, the study and measurement of the influence of factors is an important methodological approach in the analysis of banking activities. This can be seen in the works of foreign and domestic scientists who are working in this direction. In foreign literature, the determinants affecting the bank's profitability are considered in detail. It is proved that operational efficiency is a prerequisite for increasing the bank's profitability, and the low operational efficiency of high-yield banks (Martins et al., 2019).

It has been studied that when foreign banks provide more loans to the economy, cost efficiency increases, while the opposite happens in state-owned banks (Mamonov et al., 2017). Operational efficiency, which is defined as the ratio of expenses and income, is considered in the studies of Pasiouras and Kosmidou and is used to measure the impact of efficiency on the profitability of banks (Pasiouras \& Kosmidou, 2007). Accordingly, we expect that operational performance indicators will be negatively correlated with the profitability of banks.

Factors affecting the bank's profitability are considering as the relationship between investment in innovations in banking activities and bank performance (Le\&Ngo, 2020).

A group of authors, assessing the effectiveness of the banking sector of the countries of the eurozone, determined that the regulatory framework and macroeconomic environment are playing a crucial role (Apostolos et al., 2020). Similarly, a study conducted in central and Eastern European countries found that depending on the specifics of the local macroeconomic environment, the impact of bank indicators on liquidity is sometimes positive and sometimes negative (Romana \& Sargub, 2015).

A study of European banks shows that special indicators of banks, studying the relationship between the bank's performance and its volume using capital risk and liquidity, prove that the improvement of the bank's capital in order to increase liquidity depends on the size of the bank (Terraza, 2015).

Income diversification, measured as the share of interest income, has a positive impact on bank profitability only in middle and high-income countries, while in developing countries, interest income is higher than non-interest income, which has no impact on bank profitability (Petria et al., 2015).

As an indicator of bank performance, many researchers have considered the return on capital (ROE), but Virginie Terraza believes it is not enough. In comparison with ROE, ROA considered as the main indicator of the bank's profitability, taking into account the risks associated with the loan. But the disadvantage of the ROA is that it does not take into account off-balance sheet assets (Lardic \& Terraza, 2019).

As we can see from the results of the literary review, the factors affecting bank performance are divided into external (macroeconomic) and internal - specific only for banks. Although there are many works devoted to the study of factors affecting the effectiveness of the bank, research on the analysis of the banking sector of the Republic of Kazakhstan is limited.

Let's review the works of Kazakh and Russian authors on the effectiveness of banks ' activities and their influencing factors:

Management of the bank's assets and liabilities, i.e. reduction of banking losses, methods of effective risk management (Kazbekova \& Dzhubalieva, 2020; Baibossynov et al., 2020), analysis of the financial stability of the Joint-Stock Company (Lambekova \& Nurgalieva, 2017), activities of the banking sector and its impact on the financial market of the Republic of Kazakhstan (Baibulekova et al., 2019), analysis and forecasting of the main financial indicators of the bank's activities (Eveskina \& Nurgalieva, 2019), methods of evaluating the effectiveness of banks (Krikalo, 2016) methods of evaluating the effectiveness of regional banks (Vyskachkina \& Dubovaya, 2011), profitability of banks as the main indicator of its economic situation (Voloshina, 2014; Makin et al., 2019) are considered on the example of individual banks.

We believe that our article will contribute to the scientific literature on identifying factors that affect the bank's profitability. 
Methods

As of September 1, 2020, 27 banks operate in the Republic of Kazakhstan, including 15 banks with foreign participation, 12 of which are subsidiaries, and 1 bank with $100 \%$ state participation.

In comparison with the beginning of 2020, the assets of second-tier banks of the Republic of Kazakhstan increased by $10.4 \%$, liabilities - by $11.4 \%$. Losses of the banking sector amounted to 5512.1 billion tenge. The ratio of net income to total assets (ROA) is $3.42 \%$ compared to the previous year, an increase of $1.05 \%$. The ratio of net income to equity on the balance sheet (ROE) is $25.94 \%$ compared to the previous year, an increase of $6.54 \%$. Despite the current state of emergency in the country, we can note the success of the BAC sector.

The study of the structure of all income and expenses of second-tier banks of the Republic of Kazakhstan (image 1) shows the priority of the share of both non-interest income and expenses in the bank's activities.

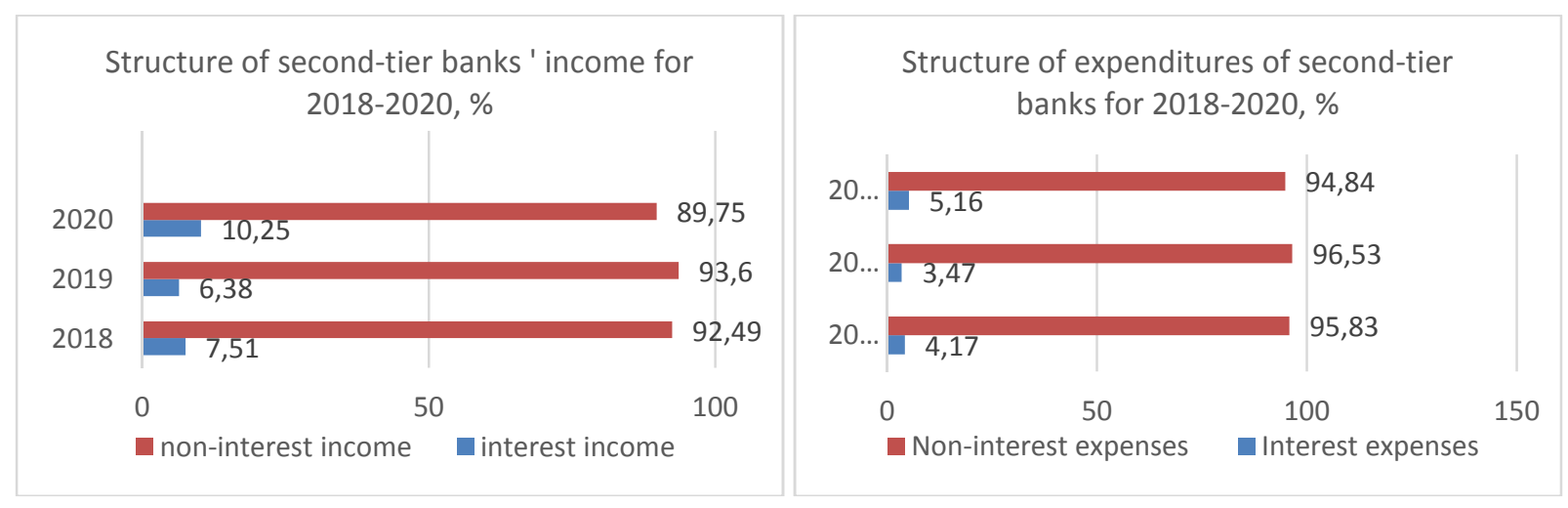

Figure 1. Structure of all revenues and expenditures of second-tier banks of the Republic of Kazakhstan

Note - Compiled by the author based on data from the National Bank of the Republic of Kazakhstan

Comparative indicators of income and expenses of second-tier banks of the Republic of Kazakhstan for the period 2018-2020 (10 months) are shown in Figure 2

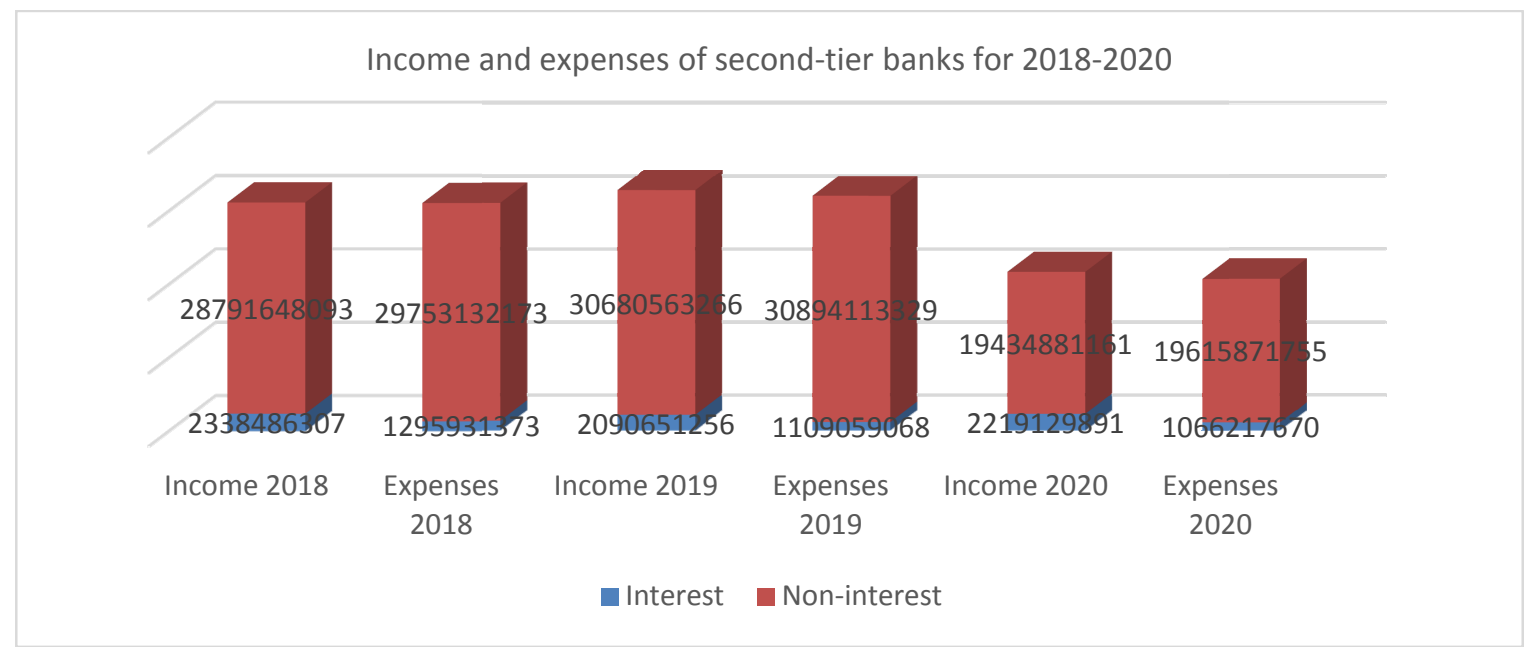

Figure 2. All income and expenses of second-tier banks of the Republic of Kazakhstan

Note - Compiled by the author based on data from the National Bank of the Republic of Kazakhstan

In order to identify factors affecting the effectiveness of the bank's activities for 2018-2020, a structural analysis of the composition of all income and expenses was carried out using the indicators published by the National Bank of the Republic of Kazakhstan. As a result, we see that more than 90 percent of the bank's income and expenses are not related to the payment of remuneration.

In this article, the object of the study is the consolidated indicators of second-tier banks of the Republic of Kazakhstan for each month from 2018 to 2020 ( 10 months of 2020). We analyze the net profit of banks, identify the factors that affect it, and determine the impact of the identified factors on net profit. 
According to the methodology of analysis of bank performance prepared by Vyskachkina O.A. and Dubovaya S. E., we consider the coefficients that affect the performance of banks activities and the level of operational efficiency (Goddard \& Molyneux,2004) as the main factor affecting net profit. Since our main goal is to determine the impact of bank expenses on profit, we will consider only those factors that are mainly related to expenses. According to the analysis of the composition of the bank's income and expenses, income from revaluation is on average $89 \%$ of all income, and expenses from revaluation are on average $81 \%$. 2018-2020 we considered the effectiveness of key operations as an individual factor in the composition of income and expenses as a whole. Our goal is to determine the impact of factors on net profit by conducting regression analysis. In order to conduct a multi-factor correlation-regression analysis of the total net profit of STBs of the Republic of Kazakhstan, the following factors were selected (Table 1).

Table 1. Factors affecting the bank's profitability

\begin{tabular}{|c|c|l|l|}
\hline № & Factors & \multicolumn{1}{|c|}{ Name of factors } & \multicolumn{1}{|c|}{ Calculation methods } \\
\hline 1 & $\mathrm{Y}$ & Net profit & Total income - Total expenses \\
\hline 2 & $\mathrm{X} 1$ & $\begin{array}{l}\text { Level of interest expense coverage by } \\
\text { interest income }\end{array}$ & Interest income / Interest expense \\
\hline 3 & $\mathrm{X} 2$ & $\begin{array}{l}\text { Level of coverage of non-interest } \\
\text { expenses by non-interest income }\end{array}$ & Non-interest income / Non-interest expenses \\
\hline 4 & $\mathrm{X} 3$ & Interest margin & Net commission income / Net interest income \\
\hline 5 & $\mathrm{X} 4$ & Return on assets & Interest income / Interest assets \\
\hline 6 & $\mathrm{X} 5$ & Liability Value Indicator & Interest expenses / Interest liabilities \\
\hline 7 & $\mathrm{X} 6$ & Operational efficiency level & Expenses / Income \\
\hline 8 & $\mathrm{X} 7$ & $\begin{array}{l}\text { The efficiency of operations based on } \\
\text { customer requirements }\end{array}$ & $\begin{array}{l}\text { Expenses related to the payment of remuneration on } \\
\text { customer claims / Income from remuneration accrued } \\
\text { to customers on bank claims }\end{array}$ \\
\hline 9 & $\mathrm{X} 8$ & $\begin{array}{l}\text { The efficiency of securities transactions } \\
\text { securities / Income related to the receipt of interest on } \\
\text { securities }\end{array}$ \\
\hline 10 & $\mathrm{X} 9$ & $\begin{array}{l}\text { The efficiency of dealing operations } \\
\text { Xxpenses for dealing operations / Income from dealing } \\
\text { operations }\end{array}$ \\
\hline 11 & $\mathrm{X} 10$ & $\begin{array}{l}\text { The efficiency of commission operations } \\
\text { Expenses for commission operations / Income from } \\
\text { commission operations }\end{array}$ \\
\hline 12 & $\mathrm{X} 11$ & The efficiency of revaluation operations & \begin{tabular}{l} 
Revaluation expenses / Revaluation income \\
\hline 13
\end{tabular} \\
\hline Note-The table was compiled by the author & $\begin{array}{l}\text { The efficiency of derivative financial } \\
\text { instruments }\end{array}$ & $\begin{array}{l}\text { Expenses on derivative financial instruments / Income } \\
\text { on derivative financial instruments }\end{array}$ \\
\hline
\end{tabular}

Using the consolidated indicators of the STB of the Republic of Kazakhstan for 2018-2020, we check the relationship between net income and independent variables through correlation analysis. First, we present the result of performing a general descriptive analysis using the Stata application program in Table 2.

Table 2. Descriptive statistics

\begin{tabular}{|l|l|l|l|l|l|}
\hline № & Variables & 2018 mean & 2019 mean & 2020 mean & $\begin{array}{l}\text { Average for three } \\
\text { years }\end{array}$ \\
\hline 1 & $\mathrm{Y}$ & 373510,3 & 392758.8 & 445688.3 & 401532,7 \\
\hline 2 & $\mathrm{X} 1$ & 1,865 & 1.977 & 2,147 & 1,987 \\
\hline 3 & $\mathrm{X} 2$ & 0,991 & 0.984 & 0,991 & 0,988 \\
\hline 4 & $\mathrm{X} 3$ & 0,368 & 0,404 & 0,340 & 0,373 \\
\hline 5 & $\mathrm{X} 4$ & 0,067 & 0,063 & 0,055 & 0,620 \\
\hline 6 & $\mathrm{X} 5$ & 0,031 & 0,028 & 0,023 & 0,027 \\
\hline 7 & $\mathrm{X} 6$ & 0,978 & 0,983 & 0,977 & 0,979 \\
\hline 8 & $\mathrm{X} 7$ & 0,536 & 0,451 & 0,426 & 0,473 \\
\hline 9 & $\mathrm{X} 8$ & 0,396 & 0,581 & 0,462 & 0,480 \\
\hline 10 & $\mathrm{X} 9$ & 0,909 & 0,787 & 0,648 & 0,789 \\
\hline 11 & $\mathrm{X} 10$ & 0,167 & 0,199 & 0,252 & 0,203 \\
\hline 12 & $\mathrm{X} 11$ & 0,998 & 1,002 & 1,001 \\
\hline 13 & $\mathrm{X} 12$ & 1,079 & 1,016 & 1,012 \\
\hline Note - The table was compiled by the author as a result of analysis using the Stata application program & \\
\hline
\end{tabular}


Banks net income increases year-on-year the average net income for the ten months of 2020 increased by 19 percent compared to 2018 and 13 percent compared to 2019.

$\mathrm{X} 1$ shows the adequacy of interest income to interest expenses, the ratio of interest income to interest expenses is 1.86 times higher in 2018, 1.97 in 2019, and 2.14 times higher in 2020, that is, in recent years we have seen an increase in interest income rates compared to interest expenses.

We can see that the ratio of non-interest income to non-interest expenses X2 is less than that of noninterest income compared to non-interest expenses, but since the value of all three years is about 1 , the situation is not so difficult. The non-interest income of STBs of the Republic of Kazakhstan is on average $91 \%$ of all income.

X3 net interest margin is determined by the ratio of net commission income and net interest income. The profit margin characterizes the effectiveness of cost management and pricing policy for the services provided by the bank (Lavrushin, 2016). In 2020, it decreased by $8 \%$ compared to 2018 , and by $16 \%$ compared to 2019.

$\mathrm{X} 4$ The return on assets is determined by the ratio of interest income to the number of assets to which interest is calculated. As a rule, the profit in asset management in developed countries is higher than in interest-bearing operations. A high share of interest income in gross income leads to a low profit of banks. However, the net percentage margin in developing countries is much higher than in developed countries (Beck et al., 2009). This figure decreased by $18 \%$ in 2020 compared to 2018 and by $13 \%$ compared to 2019, the main reason for which is the corresponding decrease in interest income.

X5 The value of liabilities is determined by the ratio of interest expenses to interest liabilities. In 2020, it decreased by $26 \%$ compared to 2018 , and by $18 \%$ compared to 2019 . The changes are mainly due to an increase in interest liabilities.

X6 The level of operational efficiency is determined by the ratio of all expenses to all revenues (Athanasoglou et al., 2006), as this indicator decreases, the bank's performance improves, in our case 0.97, $0.98,0.97$, that is, we see that all income exceeds expenses. For banks to be able to operate, their expenses must be covered by income, and the fact that this indicator is below 1 indicates the stability of the bank's activities.

When analyzing the composition of income and expenses of banks based on factors from X7 to X12, income, and expenses with an equity weight of more than $1 \%$ were obtained. Our goal is to determine the impact of operational benefits derived from the main operations of banks on net profit. The fact that these indicators are below 1 means that the income from the corresponding operation exceeds the costs, and we know that as this indicator decreases, the efficiency of this operation increases.

$\mathrm{X} 7$ customer claims and the effectiveness of operations on customer claims to the bank is determined by the ratio of expenses related to the payment of remuneration on customer claims to income from remuneration accrued on customer claims to the bank. This figure decreased by $21 \%$ in 2020 compared to 2018 , and by $6 \%$ compared to 2019 . Income from remuneration accrued to customers under the bank's claims is more than twice as much as expenses for remuneration paid to customers by the bank.

$\mathrm{X} 8$ the effectiveness of securities transactions is determined by the ratio of expenses related to the payment of interest on securities to income related to the receipt of interest on securities. This figure increased by $17 \%$ in 2020 compared to 2018 and decreased by $20 \%$ compared to 2019 . The downward trend indicates an increase in the efficiency of securities transactions. It refers to an operation with high operational efficiency.

$\mathrm{X} 9$ the effectiveness of dealing operations is determined by the ratio of expenses to income for dealing operations. Bank dealing operations arise based on the provision and implementation of transactions by bank dealers for the sale and purchase of foreign currency, the placement of deposits, securities, and gold (Varlamova \& Vasilyeva, 2007). This figure decreased by $29 \%$ in 2020 compared to 2018 , and by $18 \%$ compared to 2019. That is, we see an increase in the efficiency of dealing operations.

X10 efficiency of commission operations refers to the ratio of expenses for commission operations to income for commission operations. Commission income or expenses include income and expenses incurred in a certain amount for services rendered and works performed. In modern conditions, most banks aim to increase commission income, and many of them launch new commission products and services, as in modern conditions they have become an important source of additional profit. In Banking Practice, Commission operations include settlement and cash operations, bank card servicing, collection operations, bank guarantees, and guarantees, etc. (Maslyakova, 2017). Income from commission operations averaged 1.8\% of all revenues, while commission expenses accounted for $0.36 \%$. As you can see from Table 2 , the income 
from commission operations is on average 5 times higher than the corresponding expenses and is the most profitable operations. This figure increased by $51 \%$ in 2020 compared to 2018 and by $27 \%$ compared to 2019 , as a result of an increase in commission costs, but the efficiency of operations did not decrease.

$\mathrm{X} 11$ the effectiveness of revaluation operations is determined by the ratio of revaluation expenses to revaluation income. Both income and expenses from revaluation in STBs of the Republic of Kazakhstan, respectively, account for an average of $85 \%$ of all income and expenses. Both revaluation income and expenses in 2020 decreased by $38 \%$ compared to 2018 and by $43 \%$ compared to 2019 . The effectiveness of revaluation operations is changing to a negative one. While in 2018 this figure was 0,998 , in 2019 and 2020 we will see that this figure reaches 1,002 and a dangerous situation arises.

$\mathrm{X} 12$ the effectiveness of transactions with derivative financial instruments is determined by the ratio of expenses on derivative financial instruments to income on derivative financial instruments. Income from derivatives accounted for $1.4 \%$ of all income, while expenses from these operations accounted for $1.33 \%$ of all expenses. This figure decreased by $14 \%$ in 2020 compared to 2018 , and by $9 \%$ compared to 2019 . The effectiveness of derivative financial instruments began to stabilize by 2020 if in 2018-2019 they were in a dangerous zone.

\section{Results}

Correlation-regression analysis is a classic method of stochastic modeling economic activity. It studies the relationship between indicators of economic activity if the relationship between them is not strictly functional and is distorted under the influence of random factors. When conducting correlation-regression analysis, various correlation and regression models of economic activity are created (Baraz, 2005).

We used the method of correlation-regression analysis to determine the dependence of profits on second-tier banks in the Republic of Kazakhstan. To determine the factors of growth in the economic efficiency of banks, it is necessary to determine the interdependence between the selected indicators. We study the relationship between the selected factors and the bank's net income using correlation analysis (Figure 3)

\begin{tabular}{|c|c|c|c|c|c|c|c|c|c|c|c|c|c|}
\hline & $\mathrm{y}$ & $\mathrm{x} 1$ & $\mathrm{x} 2$ & $\mathrm{x} 3$ & $\mathrm{X} 4$ & $\mathrm{x} 5$ & $\mathrm{x} 6$ & $\mathrm{x} 8$ & $\mathrm{xg}$ & $\mathrm{x} 10$ & $\mathrm{x} 11$ & $\mathrm{X} 12$ & \\
\hline $\mathrm{y}$ & 1.0000 & & & & & & & & & & & & \\
\hline $\mathrm{x} 1$ & 0.1689 & 1.0000 & & & & & & & & & & & \\
\hline $\mathrm{x} 2$ & 0.3235 & 0.0952 & 1.0000 & & & & & & & & & & \\
\hline $\mathrm{x} 3$ & 0.3131 & -0.4131 & -0.2503 & 1.0000 & & & & & & & & & \\
\hline $\mathrm{X} 4$ & 0.7643 & -0.1190 & -0.0777 & 0.2983 & 1.0000 & & & & & & & & \\
\hline x5 & 0.7360 & -0.1963 & -0.0835 & 0.3333 & 0.9948 & 1.0000 & & & & & & & \\
\hline $\mathrm{x} 6$ & -0.3955 & -0.1942 & -0.8010 & 0.0946 & 0.0004 & 0.0049 & 1.0000 & & & & & & \\
\hline $\mathrm{x} 7$ & -0.1240 & -0.8352 & 0.1614 & 0.0664 & 0.0437 & 0.1017 & -0.0122 & 1.0000 & & & & & \\
\hline $\mathrm{X} 8$ & 0.3198 & 0.2525 & -0.2453 & 0.3869 & 0.2850 & 0.2625 & $5-0.0366$ & -0.5268 & 1.0000 & & & & \\
\hline $\mathrm{xg}$ & -0.6545 & -0.5377 & 0.0229 & -0.0171 & -0.6268 & -0.5745 & 0.0019 & 0.5073 & -0.3189 & 1.0000 & & & \\
\hline $\mathrm{X} 10$ & 0.1204 & 0.9301 & 0.0538 & -0.4331 & -0.1574 & -0.2310 & -0.0877 & -0.8619 & 0.2237 & -0.5266 & 1.0000 & & \\
\hline $\mathrm{X} 11$ & 0.3775 & 0.3252 & -0.1786 & 0.1713 & 0.5230 & 0.5055 & 0.2631 & -0.4375 & 0.2988 & -0.7944 & 0.3004 & 1.0000 & \\
\hline $\mathrm{X} 12$ & -0.2207 & -0.6017 & 0.0390 & 0.1563 & -0.2023 & -0.1679 & -0.1451 & 0.5708 & -0.1207 & 0.6898 & -0.6133 & -0.7985 & 1.0000 \\
\hline
\end{tabular}

Figure 3. Correlation analysis result

\section{Note-The image was obtained as a result of analysis using the Stata application program}

To quantify the existence of a relationship between the considered random sets, a special statistical indicator is used - the correlation coefficient $(\mathrm{R})$. the value of the correlation coefficient takes values from 0 to +-1 . Since the value of the coefficient approaches 1 , it is safe to say that there is a linear correlation between the considered sets of variables (Shanchenko, 2011). Special tables, such as the Chaddock scale, are used to assess the strength of the identified links.

In our study, the relationship between net profit and return on assets and the value of net profit and liabilities is considered strong, while the relationship between net profit and the efficiency of dealing operations is significant, and there is also a relationship between net profit and the level of operational efficiency and the level of efficiency of revaluation operations. And the relationship between other variables and net income is almost nonexistent. To make sure that the relationship is as close as possible, we test hypotheses that are calculated based on the pair correlation coefficients. 
In order to check the adequacy of the identified links, we conduct a statistical assessment, for which we compare the calculated value $\mathrm{R}_{\text {cal }}$ and table values $\mathrm{R}_{\text {tab. }}$ of the correlation coefficients.

We get the value $\mathrm{R}_{\mathrm{tab}}$. from the table where the values of the Pearson correlation coefficient for different degrees and significance levels are given.

The significance level is 0.05 and the tab value is $R$ tab. at the intersection of the number of specified dimensions (34-2) 0.3494. It is proved that there is a significant linear relationship between the considered numerical sets with the confidence of a given degree if the tabulation inequality $\mathrm{R}_{\text {cal }}>=\mathrm{R}_{\text {tab. }}$. executed. In other words, the hypothesis that the linear dependence is significant is accepted.

Comparing the calculated values of $R_{\text {cal }}$ and the table values of $R_{\text {tab }}$ variables shown in figure 3, we determine the independent variables that have a relationship with the dependent variable, the result is presented in table 3.

Table 3. The density of relationships between net profit and factors

\begin{tabular}{|c|c|c|c|c|l|}
\hline № & Factors & Value & $>=$ & $\mathrm{r}_{\text {tab }}$ value 0,3494 & Proof of hypothesis \\
\hline 1 & $\mathrm{X} 4$ & 0,7643 & $>$ & 0,3494 & Correlation is significant \\
\hline 2 & $\mathrm{X} 5$ & 0,7360 & $>$ & 0,3494 & Correlation is significant \\
\hline 3 & $\mathrm{X} 6$ & $-0,3955$ & $>$ & 0,3494 & Correlation is significant \\
\hline 4 & $\mathrm{X} 9$ & $-0,6545$ & $>$ & 0,3494 & Correlation is significant \\
\hline 5 & $\mathrm{X} 11$ & $-0,3775$ & $>$ & 0,3494 & Correlation is significant \\
\hline \multicolumn{7}{|l}{ Note-Author's calculations } \\
\hline
\end{tabular}

Factors involved in multiple regression must meet the following requirements::

1. factors involved in multiple regression should have a significant impact on the dependent variable;

2. factors should not be closely related [29, P 55].

We have identified the factors that meet the first requirement, and in the next step, we check whether the factors are interrelated, i.e. collinear, using image 3.

Since the factors, X4 and X5 are closely related to each other 0.9948 and its value is higher than 0.8 , it is impossible to calculate one of the two factors since it is impossible to determine the impact of each of them on the performance indicator.

In cases where the collinear bond of factors is strong, a factor whose pairwise bond density is less than the intermediate bond density is excluded from the study.

Regression analysis

In our example, the ratio of factors $\mathrm{X} 4$ and $\mathrm{X} 5$ to $\mathrm{Y}$ is less than 0.9948 , so we do not take $\mathrm{X} 5$ into account. Let's show the result of the regression performed by the remaining factors in Figure 4.

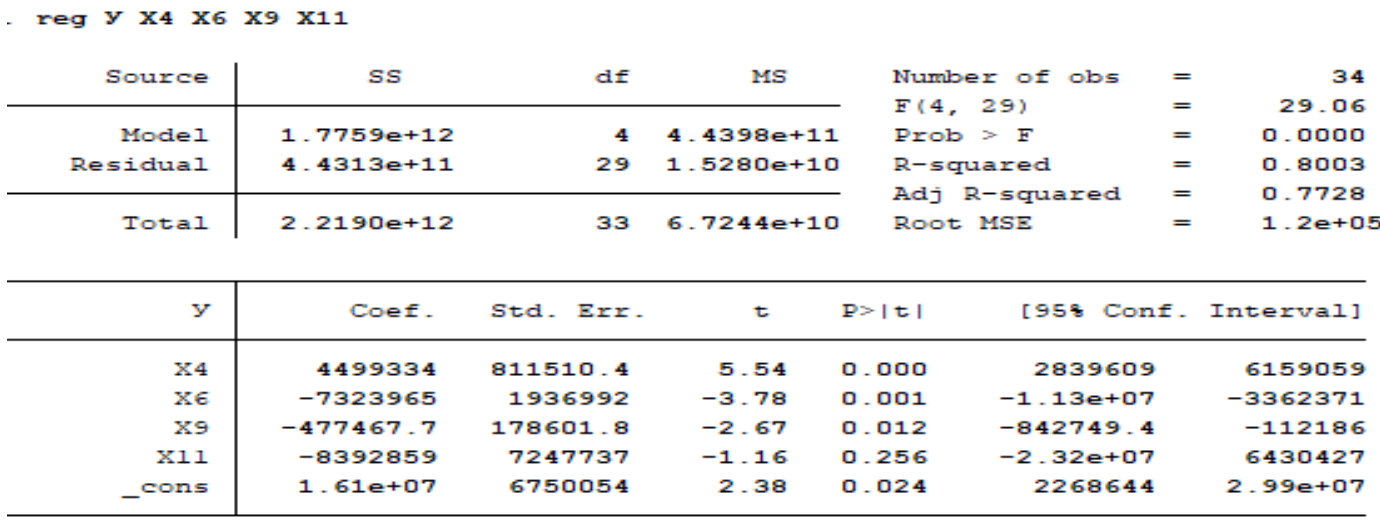

Figure 4. Regression analysis result

Note -The image was obtained as a result of analysis using the Stata application program

Thus, while correlation analysis allows us to conclude the bond density between pairs $\mathrm{Y}$ and $\mathrm{X}$, regression analysis allows us to predict the second variable (Y) based on one variable (X). The causal relationship between the analyzed sets is determined.

The model to be created based on the given data:

$$
\mathrm{y}=1,6100000+4499334 \mathrm{X}_{4}-7323965 \mathrm{X}_{6}-477467,7 \mathrm{X}_{9}-8392859 \mathrm{X}_{11}+\mathrm{e}
$$

Evaluation of the importance of the regression equation 
We evaluate the importance of the regression equation using the F-Fischer criterion. For this purpose:

- The hypothesis $\mathrm{H} 0$ is proposed that the regression equation has no significance;

- F-the tabular and calculated value of the criterion is determined. The tabular value of the criterion determined by the corresponding $\mathrm{F}$ table- 2.70 and $\mathrm{F}$ calculated - 29.06;

$-\mathrm{F}_{\text {calc }}>\mathrm{F}_{\text {table }}$ condition is checked.

The hypothesis $\mathrm{H} 0$ that the regression equation has no significance is rejected because the problem $\mathrm{F}$ calc. is $29.06>\mathrm{F}_{\text {table }}$ is 2.7 , and the equation is considered statistically significant.

Checking the significance of coefficients in the regression equation

Based on Figure 4, we formalize the result of checking the level of significance of the coefficients of the regression equation in Table 4.

Table 4. A significance level of coefficients of the regression equation

\begin{tabular}{|c|c|l|}
\hline Factors & $\mathrm{P}>\mathrm{I} \mathrm{t} \mathrm{I}$ & significance of the coefficient at the value level $\alpha 0.05$ \\
\hline $\mathrm{X} 4$ & 0,000 & significant \\
\hline $\mathrm{X} 6$ & 0,001 & significant \\
\hline $\mathrm{X} 9$ & 0,012 & significant \\
\hline $\mathrm{X} 11$ & 0,256 & not significant \\
\hline Constanta & 0,024 & significant \\
\hline Note - The table was compiled by the author as a result of analysis using the Stata application program \\
\hline
\end{tabular}

Taking into account only important factors (X4, X6, X9), we reconstruct the regression equation (fig.5).

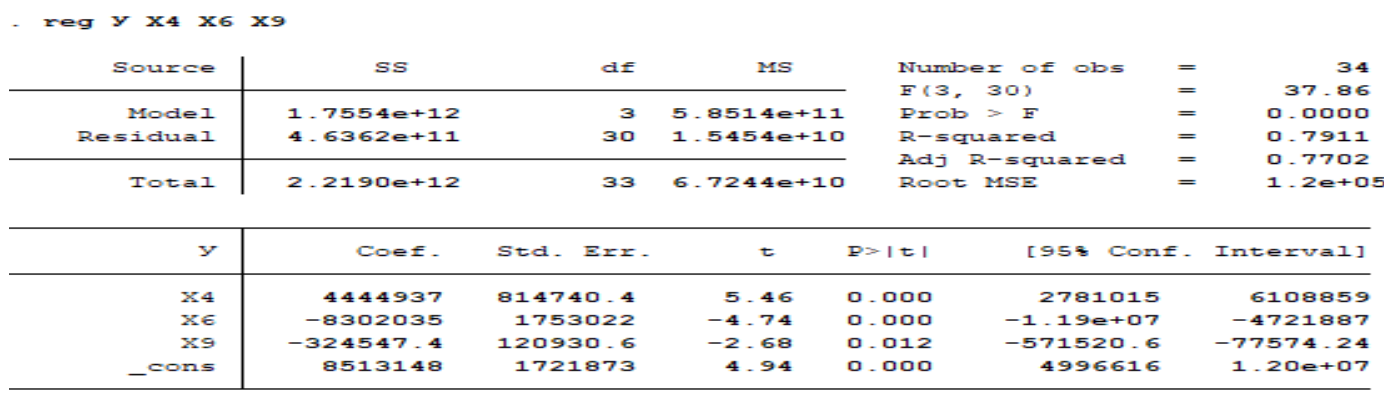

Figure 5. Regression analysis result

Note-The image was obtained as a result of analysis using the Stata application program

\section{Discussions}

Thus, analyzing the results of the analysis, we found that the profitability of second-tier banks of the Republic of Kazakhstan is influenced by three main factors::

- return on assets X4;

- operational efficiency level X6;

- the efficiency of dealing operations X9.

$$
\mathrm{Y}=8513148+4444937 \mathrm{X}_{4}-8302035 \mathrm{X}_{6}-324547,4 \mathrm{X}_{9}+\mathrm{e}
$$

According to the model, an increase in the return on assets by one point increases net income by 4444937 tenge; an increase in the level of operational efficiency by one point reduces net income by 8302035 tenge; an increase in the efficiency of dealing operations by one point reduces net income by 324547.1 tenge. These effects are relevant only if the other factors involved in the model do not change. Among these factors, the level of operational efficiency that has the greatest impact on net income. That is, as costs decrease or revenues increase, there is a greater chance of increasing net income.

The coefficient of determination $\mathrm{R}^{2}$ is used as a statistical indicator. The value of $\mathrm{R}^{2}$ in our last regression equation is 0.7911 or $79 \%$. All the influencing factors present in our model include $79 \%$ of the analyzed function X4, X6, X9, the remaining $21 \%$ require research since this is the influence of unaccounted factors. You can also use this metric to run a test and check the importance of the regression equation.

Since it is performed with the inequality $\mathrm{R}^{2}$ calculated $0.7911>\mathrm{R}^{2}$ table 0.297 , it is possible to note with $95 \%$ confidence the importance of this regression equation. 


\section{Conclusions}

Factor analysis allows us to identify the main factors affecting the bank's activities and assess the degree of their impact. As a result of the analysis of factors affecting the bank's profit in the aggregate indicator of second-tier banks of the Republic of Kazakhstan, the compliance of the results obtained with the expected results was determined.

As a result of the first correlation analysis, factors that have a significant relationship between the bank's profit and the selected factors were selected.

With $95 \%$ certainty, it was found that there is a significant linear correlation between the considered net profit sets and the X4, X5, X6, X9, X11 sets.

As a result of checking the absence of a mutual collinear relationship between the selected factors, factor X5 was excluded from the calculation.

As a result of regression analysis conducted using significant factors, a causal relationship between net profit and factors X4, X6, X9, X11 was revealed.

The result of evaluating the significance of the regression equation, which was carried out using the FFischer criterion, showed that the equation is considered statistically significant.

The significance of the coefficients of the regression equation is checked by the coefficients $p$ and the most important factors are determined.

The equation as a result of regression formed using the identified significant factors is considered adequate.

As a result of the correlation-regression analysis, the negative impact of operational efficiency on the bank's net income was proved. The return on interest assets has a positive impact on the bank's profitability, and the effectiveness of dealing operations has a negative impact.

The results of the test with the determination coefficient $\mathrm{R}^{2}$ also revealed the importance of the regression equation.

We intend to conduct this study in the future with an increase in the indicators of second-tier banks of the Republic of Kazakhstan individually and the number of stages.

\section{References}

Apostolos, G., Christopoulos Ioannis, G. Dokas \& Sofia Katsimardou. (2020). Eleftherios Spyromitros Assessing banking sectors' e ciency of financially troubled Eurozone countries. Research in International Business and Finance, $52,101-121$.

Athanasoglou, P.P., Delis, M.D. \& Staikouras, C.K. (2006). Determinants of Bank Profitability in the South Eastern European Region Bank of Greece. Working Paper, 47.

Baibossynov, S.B., Nevmatulina, K.A.\& Shakeyev, S.S. (2020). Ways of optimization and cost reduction of the enterprise. Bulletin of the Karaganda University. Economy Series, 1(97), 6-16.

Bajbulekova, L.A., Kasymbekova, G.R., \& Zajtenova, N.K. (2019). Bank sektorynyn qyzmeti zhane onyn Qazaqstan Respublikasynyn qarzhy narygyna aseri [Activities of the banking sector and its impact on the financial market of the Republic of Kazakhstan]. Orta Azialyq Ekonomıkalyq Sholu - Central Asian Economic Review, 2, $160-172$ [in Kazakh].

Baraz, V.R. (2005). Korrelyacionno-regressionnyj analiz svyazi pokazatelej kommercheskoj deyatel'nosti s ispol'zovaniem programmy Excel. [Correlation and regression analysis of the relationship between indicators of commercial activity using Excel]. - Ekaterinburg: GOU VPO «UGTU-UPI» [in Russian].

Beck, T., Demiurgic - Kant A.\& Levine, R. (2009). Financial institutions and markets across countries and over time data and analysis. World Bank Policy Research Working Paper, 49-43.

Eveskina, Zh. T.\& Nurgalieva, A.M. (2019). Analysis and forecasting of the main financial indicators of the Bank's activities. Bulletin of the National Academy of Sciences of the Republic of Kazakhstan, 3(325), 230-238.

Goddard, J. P.\& Molyneux, J. Wilson. (2004). Dynamics of Growth and Profitability in Banking. Journal of Money Credit and Banking, 36(3), 1069-1090.

Kazbekova, K.M \& Dzhubalieva, Z.U. (2020). Bank tauekelderin bagalau men basqarudyn adisnamalyq tasilderin zhetildiru [Improvement of methodological approaches to bank risk assessment and management]. Orta Azialyq Ekonomıkalyq Sholý - Central Asian Economic Review, 1, 156-172 [in Kazakh].

Krikalo, V.A. (2016). Metody ocenki jeffektivnosti raboty bankov. [Methods of evaluating the performance of banks]. Inzhiniringovye biznes i upravlencheskie organizacii razvitija - Engineering business and management development organizations, 1 [in Russian].

Lambekova, A.N., \& Nurgalieva, A.M. (2017). «Halyq Bank» Aqtsionerlik qogamynyn qarzhylyq turaqtylygyn taldau ishki audit zhuiesinin tiimdiligin arttyru quraly retinde [Analysis of financial stability of Halyk Bank joint-stock company as a tool for improving the effectiveness of the internal audit system]. Qaraǵanda ýniversitetiniń Habarshysy. Ekonomıka serıasy - Bulletin of the Karaganda University. Economy Series, 2(86), $236-242$. 
Lardic Sandrine \& Terraza Virginie. (2019). Financial Ratios Analysis in Determination of Bank Performance in the German Banking Sector. International Journal of Economics and Financial Issues, 9(3), $22-47$.

Lavrushin, O.I. (2016). Bankovskij menedzhment. [Bank management]. - Moscow: KNORUS [in Russian].

Le Ty DQ \& Ngo Thanh. (2020). The determinants of bank profitability: A cross-country analysis. Central Bank Review, 20(2), 65-73.

Makin, M.V., Konorev, A.M., Bystrickaja, A.Ju., \& Pahomova, E.V. (2019). Issledovanie jeffektivnosti deiatelnosti kommercheskogo banka. [Study of tools and methods for assessing the effectiveness of a commercial Bank]. Vestnik Evrazijskoj nauki - The Eurasian Scientific Journal, 1(11). Available at: https://esj.today/PDF/08ECVN119.pdf [in Russian].

Mamonov Mikhail \& Vernikov Andrei (2017). Bank ownership and cost efficiency: New empirical evidence from Russia. Economic Systems, 41(2), 305-319.

Martins, A.M, Serra Ana Paula \& Stevenson Simon (2019). Determinants of real estate bank profitability. Research in International Business and Finance, 49, 282-300.

Maslyakova, E.A. (2017). Strategicheskie podhody k voprosu upravleniya pribyl'yu kommercheskogo banka. [Strategic approaches to the issue of profit management of a commercial Bank]. Aktualnye problemy razvitiya finansovogo sektora - Actual problems of development of the financial sector, 5, 387-494 [in Russian].

Novosel'skaya, N.A. \& Ksenofontova, O.L. (2012). Metody faktornogo analiza pribyli kommercheskogo banka [Methods of factor analysis of profit of a commercial Bank]. Uspekhi sovremennogo estestvoznaniya - Advances in modern natural science, 4, 81-83 [in Russian].

Pasiouras, F.\& Kosmidou, K. (2007). Factors influencing the profitability of domestic and foreign commercial banks in the European Union. Research in International Business and Finance, 21(2), 222-237.

Petria Nicolae, Capraru Bogdan \& Ihnatov Iulian. (2015). Determinants of Banks' Profitability: Evidence from EU 27 Banking Systems. Procedia Economics and Finance, 20, 518-524.

Romana Angela \& Sargub Alina Camelia. (2015). The impact of bank-specific factors on the commercial banks liquidity: empirical evidence from CEE countries. Procedia Economics and Finance, 20, 571 - 579.

Shanchenko, N.I. (2011). Ekonometrika: laboratornyj praktikum. [Econometrics: laboratory practice]. N.I. SHanchenko. Ul'yanovsk: UlGTU [in Russian].

Terraza, V. (2015). The effect of bank size on risk ratios: Implications of banks' performance. Procedia Economics and Finance, 30, 903-909.

Varlamova, T.P., Vasil'eva, N.A. \& Neganova, L.M. et al. (2007). Otv. red. N.V. Dubenyuk Bol'shaya sovremennaya enciklopediya Ed. [Big modern encyclopedia]. Moscow: Izdatelstvo «Eksmo» [in Russian].

Voloshina, O.B. (2014). Dokhodnost' banka kak odin iz osnovnykh pokazatelej ego e'konomicheskogo polozheniya [Bank Profitability as one of the main indicators of its economic position]. Izvestiya vysshikh uchebnykh zavedenij. Povolzhskij region. Obshchestvennye nauki - News of higher educational institutions. Volga region. Social science, 1(29), 158-172 [in Russian].

Vyskachkina, O.A. \& Dubovaya, S.E. (2011). Metodika ocenki jeffektivnosti dejatel'nosti regional'nogo banka [Methodology for evaluating the effectiveness of the regional Bank]. Zhurnal: Izvestija vysshih uchebnyh zavedenij - Journal: proceedings of higher educational institutions, 2, 21-27 [in Russian].

Zhakupova, A.A. \& Niyazbekova, Sh.U. (2020). Financial planning as a tool for strengthening the company's financial stability. Bulletin of the Karaganda University. Economy Series, 3(99), 134-142.

QR Ylttyq bank molimetteri [Data of the National Bank of the Republic of Kazakhstan]. Retrieved from https://nationalbank.kz/kz/news/svodnyy-otchet-o-dohodah-i-rashodah/rubrics/1463_[in Kazakh].

\section{Ж.Т. Евескина, А.М. Нургалиева, Л.А. Чайковская}

\section{Екінші деңгейдегі банктердің табыстылығы: мәні және әсер етуші негізгі факторлар}

\section{Ацдатnа}

Maқ̧cambl: Мақалада ҚР екінші деңгейлі банктерінің жиынтық көрсеткіштерінің негізінде банктің таза табысына қандай факторлардың және қалай әсер ететіндігін айқындау.

Әдістері: Талдау барысында Stata статистикалық пакетінің көмегімен банк мәліметтеріне корреляциялықрегрессиялық талдау жасалып, қорытындылар жасалды.

Қорытынды: Банктердің табыстылығына әсер ететін факторларды анықтау үшін таңдалған көрсеткіштер арасындағы өзара тәуелділіктер анықталды. Корреляциялық талдау арқылы таңдап алынған факторлар мен банктің таза табысы арасындағы байланыстар айқындалды. Байланыстардың тығыздылығын жұптық корреляция коэффициенттеріне негізделіп есептелетін гипотезаларды тексере отырып анықталды.

Тұжырымдама: Жүргізілген факторлық талдау банк қызметіне әсер ететін негізгі факторларды анықтауға және олардың әсер ету дәрежесін бағалауға мүмкіндік берді. ҚР екінші деңгейлі банктерінің жиынтық көрсеткіші бойынша банк табысына әсер ететін факторларды талдау нәтижесінде алынған нәтижелердің күтілетін нәтижелерге сәйкестігі табылды.

Кілm сөздер: банк тиімділігі, банктік кірістер, банктік шығыстар, таза табыс, операциондық тиімділік, корреляциялық талдау, регрессиялық талдау. 


\section{Ж.Т. Евескина, А.М. Нургалиева, Л.А.Чайковская}

\section{Прибыльность банков второго уровня: сущность и основные влияющие факторы}

\section{Аннотация}

Цель: В статье на основе сводных показателей банков второго уровня РК было определено влияние факторов на чистый доход банка.

Meтоды: В ходе анализа был проведен корреляционно-регрессионный анализ данных банка с помощью статистического пакета Stata и сделаны выводы.

Pезультаты: Выявлены взаимозависимости между выбранными показателями для определения факторов, влияющих на доходность банков. Корреляционным анализом определены связи между выбранными факторами и чистой прибылью банка. Взаимозависимость связей проверялась гипотезами, рассчитанными на основе коэффициентов парной корреляции.

Bblвoдbl: Проведенный факторный анализ позволил выявить основные факторы, влияющие на деятельность банка, и оценить степень их влияния. На основе анализа установлено соответствие полученных результатов ожидаемым прогнозам.

Ключевые слова: банковская эффективность, доходы банка, расходы банка, чистая прибыль, операционная эффективность, корреляционный анализ, регрессионный анализ.

\section{References}

Apostolos G., Christopoulos Ioannis, G. Dokas, Sofia Katsimardou \& Eleftherios Spyromitros Assessing banking sectors' e ciency of financially troubled Eurozone countries // Research in International Business and Finance. 2020. - 52. - P. 101-121.

Athanasoglou P.P., Delis, M.D.\& Staikouras C.K. Determinants of Bank Profitability in the South Eastern European Region Bank of Greece // Working Paper. - 2006. - 47.

Baibossynov S.B., Nevmatulina K.A., Shakeyev S.S. Ways of optimization and cost reduction of the enterprise// Bulletin of the Karaganda University. Economy Series. - 2020. - 1(97). - P. 6-16.

Beck, T., Demiurgic - Kant A. \& Levine, R. Financial institutions and markets across countries and over time - data and analysis //World Bank Policy Research Working Paper. - 2009. - P. 49-43.

Eveskina Zh. T. \& Nurgalieva A.M. Analysis and forecasting of the main financial indicators of the Bank's activities // Bulletin of the National Academy of Sciences of the Republic of Kazakhstan. - 2019. - 3(325). - P. 230-238.

J. Goddard P.\& Molyneux J. Wilson Dynamics of Growth and Profitability in Banking // Journal of Money Credit and Banking. -2004. -36 (3). - P.1069-1090.

Lardic Sandrine \& Terraza Virginie. Financial Ratios Analysis in Determination of Bank Performance in the German Banking Sector// International Journal of Economics and Financial Issues. - 2019. — 9(3). — P. 22-47.

Le Ty DQ \& Ngo Thanh. The determinants of bank profitability: A cross-country analysis //Central Bank Review. 2020. - 20(2). - P. 65-73.

Mamonov Mikhail \& Vernikov Andrei. Bank ownership and cost efficiency: New empirical evidence from Russia IEconomic Systems. - 2017. - 41(2). - P. 305-319.

Martins Antonio Miguel, Serra Ana Paula \& Stevenson Simon. Determinants of real estate bank profitability // Research in International Business and Finance. - 2019. - 49. - P.282-300.

Pasiouras F., Kosmidou K. Factors influencing the profitability of domestic and foreign commercial banks in the European Union //Research in International Business and Finance. - 2007. - 21 (2). - P. 222-237.

Petria Nicolae, Capraru Bogdan \& Ihnatov Iulian. Determinants of Banks' Profitability: Evidence from EU 27 Banking Systems //Procedia Economics and Finance. - 2015. - 20. - P. 518-524.

Romana Angela \& Sargub Alina Camelia. The impact of bank-specific factors on the commercial banks liquidity: empirical evidence from CEE countries//Procedia Economics and Finance. - 2015. - 20. - P. 571 - 579.

Terraza, V. The effect of bank size on risk ratios: Implications of banks' performance// Procedia Economics and Finance. - 2015. - 30. -P. 903-909.

Zhakupova A.A., Niyazbekova Sh.U. Financial planning as a tool for strengthening the company's financial stability // Bulletin of the Karaganda University. Economy Series. - 2020. - 3(99). - P. 134-142.

Байбулекова Л.А. Банк секторының қызметі және оның Қазақстан Республикасының қаржы нарығына әсері / Л.А. Байбулекова, Г.Р. Касымбекова, Н.К. Зайтенова // Central Asian Economic Review. — 2019. - 2. Б. $160-172$.

Бараз В.Р. Корреляционно-регрессионный анализ связи показателей коммерческой деятельности с использованием программы Excel: учеб. пос. / В.Р. Бараз. - Екатеринбург: ГОУ ВПО «УГТУ-УПИ», 2005. $-102 \mathrm{c}$.

Варламова Т.П. Большая современная энциклопедия / Т.П. Варламова, Н.А. Васильева, Л.М. Неганова и др.; Отв. ред. Н. В. Дубенюк. - М.: Изд-во «Эксмо», 2007. — С. 190. 
Волошина О.Б. Доходность банка как один из основных показателей его экономического положения / О.Б. Волошина // Изв. высш. учеб. зав. Поволжский регион. Общественные науки. — 2014. — 1(29). — C. $158-172$.

Выскачкина О.А. Методика оценки эффективности деятельности регионального банка / О.А. Выскачкина, С.Е. Дубовая // Изв. высш. учеб. зав. - 2011. - 2. - С. 21-27.

Қазбекова Қ.М. Банк тәуекелдерін бағалау мен басқарудың әдіснамалық тәсілдерін жетілдіру / Қ.М. Қазбекова, 3.У. Джубалиева // Central Asian Economic Review. — 2020. — 1. - Б.156-172.

Крикало В.А. Методы оценки эффективности работы банков / В.А. Крикало // Инжиниринговые бизнес- и управленческие организации развития. - 2016. - 1.

Лаврушин О.И. Банковский менеджмент: учеб. / О.И. Лаврушин. - М.: КНОРУС, 2016. — 560 с.

Ламбекова А.Н. «Халық Банк» Акционерлік қоғамының қаржылық тұрақтылығын талдау ішкі аудит жүйесінің тиімділігін арттыру құралы ретінде // А.Н. Ламбекова, А.М. Нургалиева // Қарағанды университетінің хабаршысы. Экономика сериясы. - 2017. - 2(86). - Б. 236-242.

Макин М.В. Исследование эффективности деятельности коммерческого банка / М.В. Макин, А.М. Конорев, А.Ю. Быстрицкая, Е.В. Пахомова // Вестн. Евраз. науки. — 2019. — 1 // https://esj.today/PDF/08ECVN119.pdf (доступ свободный).

Маслякова Е.А. Стратегические подходы к вопросу управления прибылью коммерческого банка / Е.А. Маслякова // Актуальные проблемы развития финансового сектора. — 2017. — 5. - С. $387-494$.

Новосельская Н.А. Методы факторного анализа прибыли коммерческого банка / Н.А. Новосельская, О.Л. Ксенофонтова // Успехи современного естествознания. - 2012. - 4. — С. 81-83.

Шанченко Н.И. Эконометрика: лабораторный практикум: учеб. пос. // Н.И. Шанченко. — Ульяновск: УлГТУ, 2011. - $117 \mathrm{c.}$

ҚР Ұлттық банк мәліметтері интернеттен алынған. https://nationalbank.kz/kz/news/svodnyy-otchet-o-dohodah-irashodah/rubrics/1463 